\title{
Quality Standards for Caturjata Carna Evaluated with Official and Substitute Ingredients
}

\author{
Research Article
}

\section{Koppala Narayana Sunil Kumar ${ }^{1 *}$, Rao Priyadarshini², Muthu Tamizh Manoharan ${ }^{3}$, Rubeena M1}

\author{
1. Department of Pharmacognosy, 3. Department of Chemistry, \\ Siddha Central Research Institute, Central Council for Research in Siddha, Arumbakkam, Chennai, \\ 2. Department of Pharmacognosy, SDM Centre for Research in Ayurveda and Allied Sciences, Udupi.
}

\begin{abstract}
Background: In Ayurveda, single or multiple herbs mixed in a particular proportion are used for the treatment of different diseases. Caturjata Curna (CC) is a popular Ayurvedic medicine with therapeutic application in tastelessness, diseases due to vitiated Kapha, poisoning and discoloration. The present study is an attempt to standardize a polyherbal medicine CC. Methods: CC was prepared by mixing an equal proportion of ingredients including Tvak (Cinnamomum verum) - stem bark, Ela (Elettaria cardamomum (L.) Maton) - seed, Tvakpatra (Cinnamomum tamala (Buch.-Ham.) T.Nees \& Eberm.) - leaf and Nagakesara (Mesua ferrea L.) - stamen in equal parts as per guidelines in Ayurvedic Formulary of India. Macro-microscopy, physico-chemical parameters, HPTLC fingerprinting, and spectroscopic parameters were determined according to standardised methodology available in Ayurvedic Pharmacopoeia of India. Results: Caturjata curna is brown coloured with a characteristic odour and aromatic taste. Powder microscopy showed the presence of diagnostic characters like horse shoe-shaped stone cells, perisperm cells with volatile oil droplets, paracytic stomata and endothecium layers of anthers indicating each ingredient of the formulation. HPTLC showed 13, 13 and 16 bands each under short UV, long UV and white light post derivatisation respectively in ethanolic extract of the formulation. Physico-chemical standards like loss on drying at $105^{\circ}(10.39 \%)$, total ash $(4.1 \%)$, acid-insoluble ash $(0.90 \%)$, ethanol- soluble extractive $(10 \%)$, water-soluble extractive $(8.77 \%)$ and $\mathrm{pH}$ of $10 \%$ aqueous solution (4.58) were recorded. The presence of cinnamaldehyde and 1eicosene was confirmed by GC-MS and NMR studies. Conclusion: a monograph on quality standards for CC has been proposed which would serve as a document to control the quality of this polyherbal formulation.
\end{abstract}

Key Words: HPTLC, GC-MS, NMR, Polyherbal drugs, Standardisation, Substitute drugs, Tastelessness, Quality control.

\section{Introduction}

Herbal medicines are popular over synthetic drugs because of the efficacy, lesser side effects and affordability. According to EMEA (European Agency for the Evaluation of Medicinal products), the term "herbal drugs" denotes plants or plant parts that have been converted into phytopharmaceuticals by means of simple processes involving harvesting, drying, and storage (1). In India, herbal medicines are mainly based on the Ayurvedic system. The World Health Organization estimates that $80 \%$ of the word's inhabitants still rely mainly on traditional medicines for their health care (2). One of the major problems hindering the acceptance of herbal medicines is the lack of standard quality control profile documentation. The

* Corresponding Author:

Koppala Narayana Sunil Kumar

Department of Pharmacognosy, Siddha Central

Research Institute,

AA Govt. Hospital Campus, Arumbakkam,

Chennai, 600106. India

Email Id: kn.sunil@gov.in task of standardisation is really challenging due to variation in composition profile of single herbs and formulations made up of multiple herbs. Due to the complex nature and inherent variability of the constituents of plant-based drugs, it is difficult to establish quality control parameters for herbal drugs (3). The property of herbal medicine depends mainly upon the composition of chemical phyto-constituents in their extracted final product. Owing to the variability and complexity of chemical constituents present in herbal plant-based drugs there is a current need to develop a method for establishing quality control parameters for Ayurvedic formulations (4). Identification, isolation, purification and characterization of active ingredients in crude extracts from herbal plants is now possible relatively easily because of the development and implementation of high resolution separating analytical techniques like RP-HPLC (5).

To make the task still more challenging, in most of the cases, preparations are either with plants of mistaken identity or deliberate substitution due to the availability of cheaper substitutes. Thus standardization of the herbal formulations is an essential factor in order 
Sunil Narayana K N et.al., Quality Standards for Caturjata curna-A Polyherbal Powder Formulation of Ayurveda

to assess the quality, purity, safety and efficacy of drugs (6).

Ancient Ayurvedic classical text Sarangdhar Samhita dating to $13^{\text {th }}$ century A.E. explained the concept of polyherbal combinations to achieve greater therapeutic efficacy compared to single-drug therapy. Combination of the multiple herbs based on its Ayurvedic properties, better therapeutic effects are rendered with lesser toxicity (7). It is known that Ayurvedic herbals are prepared in a number of dosage forms, in which mostly all of them are polyherbal formulations (8). Another ancient Ayurvedic classical text Charaka Samhita (dates of composition are uncertain) described that Ayurvedic medicines have adverse effects when prepared or used inappropriately (9), which emphasizes the correct standardization of the formulations before administering to the patients.

Caturjata Curna (CC) is an important Ayurvedic polyherbal formulation used for the treatment of diseases like tastelessness, diseases due to vitiated Kapha, poison and discoloration mentioned by Acharya Sharngdhara during $13^{\text {th }}$ Century A.D. $(7,10)$. The ingredients of CC are Cinnamomum verum J.Presl stem bark, Elettaria cardamomum (L.) Maton seed, Cinnamomum tamala (Buch.-Ham.)T.Nees \& Eberm. leaf and Mesua ferrea L. stamens at equal proportions. In the current study, CC prepared by standard method of preparation of curna detailed in Ayurvedic Formulary of India (10) was attempted for pharmacopoeial testing with reference to macro-microscopic, physico-chemical, high- performance thin layer chromatography (HPTLC)and spectroscopic parameters to obtain monographic data on its quality standards.

\section{Material and Methods}

\section{Collection and identification of plant samples}

Dry plant materials as per formula composition were collected from the raw drug section of SDM Ayurveda Pharmacy, Udupi. The plant materials were authenticated by macro-microscopy by Dr KN Sunil Kumar, Senior Research Officer, Department of Pharmacognosy, SDM Centre for Research in Ayurveda and Allied Sciences, Udupi, and voucher specimens of the raw drugs (No. SDM/UGC-MRP/CC/01-05) have been deposited in the crude drug museum (Figure 1).

\section{Preparation of Caturjata curna}

All the ingredients were washed properly to have no microbial load (11). The washed and dried raw drugs (Figure 1) of pharmacopoeial quality were finely powdered. The individual raw drug powders were passed separately through sieve number 44 followed by 85. Each ingredient was weighed separately and mixed together in the proportion specified (1 part each) and passed through sieve number 44 to obtain a homogenous blend and packed in an air-tight container (12). One $\mathrm{kg}$ of the formulation was prepared at the laboratory using standardized ingredients. Apart from using Mesua ferrea as the true ingredient, another set of the formulation was similarly prepared using Mammea suriga (Buch.-Ham. ex Roxb.) Kosterm, the substitute drug, for comparison.

\section{Ethanol soluble extractive}

Accurately $4 \mathrm{~g}$ of the sample was weighed in a glass flask with a stopper. $100 \mathrm{ml}$ of ethanol (90\%) was added. The flask was allowed to stand for 18 hours shaking occasionally every 6 hours. The content was filtered rapidly taking care not to lose any solvent. Twenty-five $\mathrm{ml}$ of the filtrate was pipetted out to a preweighed $100 \mathrm{ml}$ beaker. It was evaporated to dryness on a water bath. It was kept in hot air oven at $105^{\circ} \mathrm{C}$ for 6 hours, cooled in a desiccator for 30 minutes and weighed. The percentage of ethanol extractable matter of the sample was calculated. The experiment was repeated twice, and the average value was taken.

Figure 1. Macroscopy of ingredients/ substitutes of Caturjata curna
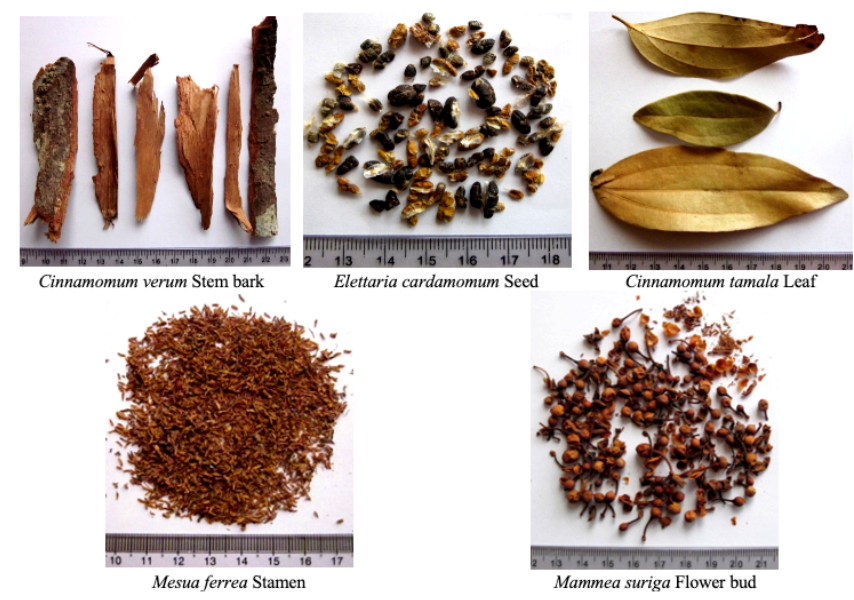

Elettaria cardamomum Seed

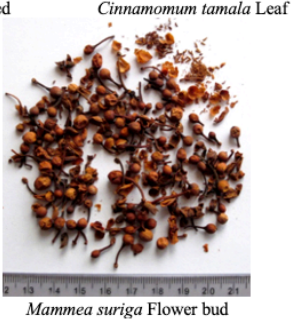

\section{Water-soluble extractive}

It was performed just like the procedure of ethanol soluble extractive but using distilled water as solvent.

\section{Microscopy and physico-chemical standardisation}

Powder microscopy of formulations and physico-chemical tests like total ash, water-soluble ash, acid insoluble ash, water and ethanol-soluble extract, loss on drying at $105^{\circ} \mathrm{C}$ and $\mathrm{pH}$ were performed following standard pharmacopoeial procedures (13).

\section{Powder microscopy}

A pinch of $\mathrm{CC}$ was mounted on a microscopic slide with a drop of glycerin-water. Characters were observed using Zeiss trinocular microscope attached with Zeiss AxioCam Erc5s digital camera under bright field light. Photomicrographs of diagnostic characters were captured and documented. Magnifications of the figures were indicated by the scale-bars.

\section{Loss on drying at $1^{\circ} \mathrm{C}$}

Ten grams of sample was placed in a tared evaporating dish. It was dried at $105^{\circ} \mathrm{C}$ for 5 hours in a hot air oven and weighed. The drying was continued until the difference between two successive weights was not more than $0.01 \%$ after cooling in a desiccator. The percentage of moisture was calculated with reference to the weight of the sample. 


\section{Total Ash}

Two grams of sample was incinerated in a tared platinum crucible at temperature not exceeding $450^{\circ} \mathrm{C}$ until carbon free ash is obtained. Percentage of ash was calculated with reference to weight of the sample.

\section{Acid insoluble Ash}

To the crucible containing total ash, $25 \mathrm{ml}$ of dilute $\mathrm{HCl}$ was added and boiled. The insoluble matter was collected on ash-less filter paper and it was washed with hot water until the filtrate is neutral. The filter paper containing the insoluble matter was transferred to the original crucible, dried on a hot plate, and ignited to constant weight. The residue was allowed to cool in a suitable desiccator for 30 mins and weighed without delay. The content of acid-insoluble ash with reference to the air-dried drug was calculated.

\section{Determination of $\mathrm{pH}$}

One gram of sample was taken; $10 \mathrm{ml}$ of distilled water was added, stirred well, and filtered. The filtrate was used for the experiment. The $\mathrm{pH} 4$ solution was first introduced and the $\mathrm{pH}$ was adjusted by using the knob to 4.02 for room temperature $30^{\circ} \mathrm{C}$. The $\mathrm{pH} 7$ solution was introduced and the $\mathrm{pH}$ meter adjusted to 7 by using the knob. Introduced the $\mathrm{pH} 9.2$ solution and checked the $\mathrm{pH}$ reading without adjusting the knob. Then the sample solution was introduced and reading was noted. Repeated the test four times and the average reading was taken as a result.

\section{Qualitative HPTLC fingerprinting Sample preparation}

One gram of each of the ingredients was extracted with $10 \mathrm{ml}$ of chloroform and filtered. The filtrates were concentrated separately and made up to 10 $\mathrm{ml}$ in a standard flask individually.

Caturjata curna with Mesua ferrea or Mammea suriga $5 \mathrm{~g}$ were extracted with $150 \mathrm{ml}$ of chloroform using Soxhlet apparatus. The filtrate was concentrated and made up to $10 \mathrm{ml}$ in a standard flask.

Mobile phase Toluene: ethyl acetate: formic acid (4.5: 0.5: 0.1) gave optimum separation. A comparative fingerprint of $\mathrm{CC}$ prepared using substituent Mammea suriga was developed using toluene: ethyl acetate (5: 1).

\section{Application, development and densitometry:}

Two concentrations such as 4 and $8 \mu$ of extract of CC were applied on aluminium plate precoated with silica gel $60 \mathrm{~F}_{254}$ of $0.2 \mathrm{~mm}$ thickness (Merck, Germany) using LINOMAT 5 applicator (CAMAG). The plates were developed in a CAMAG glass twin trough chamber previously saturated with the mobile phase. The plate was dipped in vanillinsulphuric acid (VS), and heated at $105{ }^{\circ} \mathrm{C}$ till the spots appeared $(14,15)$. The developed plates were visualized in CAMAG visualizing chamber and scanned in CAMAG SCanner 4 under $254 \mathrm{~nm}, 366$ $\mathrm{nm}$ and at $620 \mathrm{~nm}$ post-derivatisation with vanillinsulphuric acid spray reagent with the help of
CAMAG Win CATS software. $R_{f}$ values and densitograms were recorded.

\section{NMR and GC-MS Analyses}

Two grams of CC were soaked with $25 \mathrm{~mL}$ of dichloromethane for $24 \mathrm{hr}$. Then the mixture was filtered through Whatman filter paper no.1 and the filtrate was submitted for GC-MS. The filtrate was evaporated to dryness and it was employed for NMR analysis

GC-MS

GC-MS analysis of the extract of $\mathrm{CC}$ was performed using an Agilent 7890B GC comprising an auto-sampler coupled with an Agilent $7000 \mathrm{G}$ triple quadrupole GC MS system equipped with an Agilent HP-5MS (5\% diphenyl / 95\% dimethyl polysiloxane) fused a capillary column $(30 \mathrm{~m} \times 0.25$ $\mu \mathrm{m}$ ID $\times 0.25 \mu \mathrm{m} \mathrm{df}$ ). For GC separation, an injection volume of $2 \mu 1$ was employed (split ratio of 20:1). The injector temperature was maintained at $280{ }^{\circ} \mathrm{C}$, the oven temperature was programmed from $70^{\circ} \mathrm{C}$, with an increase of $15^{\circ} \mathrm{C} / \mathrm{min}$ to $150^{\circ} \mathrm{C}$ for 3 minutes, then increased by $20^{\circ} \mathrm{C} / \mathrm{min}$ to 270 ${ }^{\circ} \mathrm{C}$, ending with a $15 \mathrm{~min}$ isothermal at $270{ }^{\circ} \mathrm{C}$. For detection, an electron ionization system was operated in electron impact mode. Helium gas $(99.999 \%)$ was used as a carrier gas at a constant flow rate of $1 \mathrm{ml} / \mathrm{min}$ and the. Mass spectra were taken at $70 \mathrm{eV}$; a scan interval of $0.5 \mathrm{~s}$ was used and fragments from 25 to $550 \mathrm{Da}$ were identified. The solvent delay was 0 to $3 \mathrm{~min}$ and the run time was 29 min. Agilent Mass Hunter workstation software was used for data acquisition and analysis.

\section{NMR analysis}

The ${ }^{1} \mathrm{H}$ and ${ }^{13} \mathrm{C}\left\{{ }^{1} \mathrm{H}\right\}$ NMR spectra for the dried extract of the formulation were recorded in $\mathrm{CDCl}_{3}$ solution on BrukeAvance IV 500 spectrometer at $500.13\left({ }^{1} \mathrm{H}\right)$ and $125.35\left({ }^{13} \mathrm{C}\right) \mathrm{MHz}$ respectively. Topspin 3.5 software was used for data acquisition and analysis.

\section{Results}

\section{Microscopic features of powder of each herb}

$\mathrm{CC}$ is a brown coloured fine powder with a characteristic odour and aromatic taste. Under the microscope it shows parenchyma with tannin and volatile oil, horse-shoe shaped stone cells, narrow lumened thick-walled tapering ended fibres; cells of testa with reddish-brown contents, irregularly walled perisperm cells with volatile oil droplets; unicellular conical covering trichomes with attached basal cells, epidermis in surface view with paracytic stomata; trichome with pointed and blunt tip, polygonal beaded epidermal cells of anther, endothecium layers of anthers. Incorporation of substitute drug $M$. suriga shows the presence of epidermis of petal with striated cuticle and pollen grains with warty exine (Figure 2). 
Sunil Narayana K N et.al., Quality Standards for Caturjata curna-A Polyherbal Powder Formulation of Ayurveda

Physico-chemical constants of each raw drugs of Caturjata curna and Caturjata curna containing Mesua ferrea or Mammea suriga

Loss on drying indicates the amount of water present in the sample; foreign matter is the presence of materials other than the part to be used; total ash is to find some of the physiological and non-physiological salts; to find out the silica or sand, acid insoluble ash is done; water-soluble ash is the water-soluble part of total ash indicating the inorganic content; to find out the percentage of active constituents, ethanol and watersoluble extractives are done. These physico-chemical values of ingredients (Table 1) indicate chemical standards of raw drugs used in the present study. In the formulation using Mammea suriga as Nagakesara minor difference in a few of physico-chemical constants such as total ash $(+1.49)$, ethanol-soluble extractive $(-2.85)$, and water-soluble extractive $(+0.98)$ were observed (Table 2).

Table 1. Physico-chemical constants of raw materials used for the preparation of Caturjata Curna

Name of the ingredients

\begin{tabular}{|l|c|}
\hline Cinnamomum verum & $9.18 \pm 0$ \\
\hline Elättaria cardamomum & $20.49 \pm 0.091$ \\
\hline Cinnamomum tamala & $16.99 \pm 0.687$ \\
\hline Mesua ferrea & $11.66 \pm 0.039$ \\
\hline Mammea suriga & $12.66 \pm 0.006$ \\
\hline
\end{tabular}

Results expressed as \% $\mathrm{w} / \mathrm{w}(\mathrm{n}=3)$

\section{TA}

\begin{tabular}{|c|c|}
\hline $11.36 \pm 0.018$ & $0.69 \pm 0.064$ \\
\hline $6.89 \pm 0.008$ & $2.78 \pm 0.168$ \\
\hline $3.38 \pm 0.117$ & $0.42 \pm 0.2$ \\
\hline $4.22 \pm 0.069$ & $1.88 \pm 0.088$ \\
\hline $8.85 \pm 0.088$ & $2.89 \pm 0.275$ \\
\hline
\end{tabular}

ESE

$7.36 \pm 0.85$

$3.99 \pm 0.006$

$8.95 \pm 0.019$

$16.25 \pm 0.298$

$7.84 \pm 0.171$
WSE

$7.48 \pm 0.060$

$10.25 \pm 0.99$

$14.99 \pm 0.098$

$5.95 \pm 0.054$

$11.99 \pm 0.199$

LOD - Loss on drying at $105^{\circ}$; TA - Total ash; AIA - Acid Insoluble ash; WSE - Water soluble extractive; ESE Ethanol soluble extractive;

* Bark with outer cork was used for the study

Figure 2. Microscopic features of powder of each ingredient of Caturjata Curna

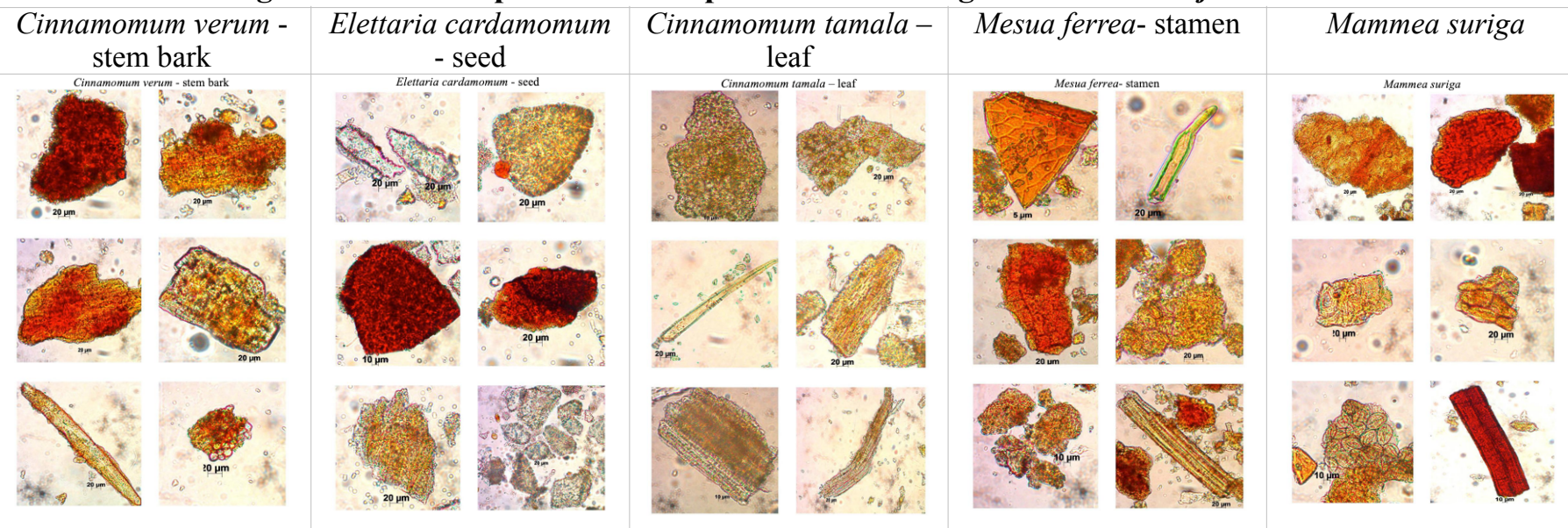

Table 2. Difference in physico chemical constants of Caturjata cūrṇa prepared using Mesua ferrea and Mammea suriga

\begin{tabular}{|l|c|c|}
\hline $\begin{array}{c}\text { Parameters } \\
\text { (\%w/w) }\end{array}$ & $\begin{array}{c}\text { Caturjata curna } \\
\text { with } \\
\text { M. ferrea }\end{array}$ & $\begin{array}{c}\text { Caturjata curna } \\
\text { with } \\
\text { M. suriga }\end{array}$ \\
\hline LOD & 10.39 & 10.60 \\
\hline TA & 4.1 & 5.59 \\
\hline AIA & 0.90 & 1.20 \\
\hline ESE & 10.0 & 7.15 \\
\hline WSE & 8.77 & 9.75 \\
\hline pH of 10\% aqueous & 4.58 & 4.42 \\
\hline Solution & & \\
\hline
\end{tabular}

LOD - Loss on drying at $105^{\circ}$; TA - Total ash; AIA Acid Insoluble ash; WSE - Water soluble extractive; ESE Ethanol soluble extractive; * Bark with outer cork was used for the study
TLC photo of chloroform extract of Caturjata Curna and its ingredients

Under short UV, Cinnamomum verum - stem bark, Elettaria cardamomum - seed, Cinnamomum tamala - leaf, Mesua ferrea - stamen and CC showed 7, 2, 11, 12 and 13 bands (all green) respectively. Thirteen bands occurred in $\mathrm{CC}$, of them 11 corresponded in $\mathrm{R}_{\mathrm{f}}$ to bands from ingredients. Bands with $\mathrm{R}_{\mathrm{f}} 0.08$ was detected in Mesua ferrea; 0.14 in Cinnamomum verum and Mesua ferrea; 0.23 in Cinnamomum verum and Mesua ferrea; 0.29 was detected in all the ingredients except in Elettaria cardamomum; 0.37 and 0.46 were detected in Cinnamomum verum and Mesua ferrea respectively; 0.50 was observed in all the ingredients except in Mesua ferrea; 0.63 was found in all the ingredients; 0.70 and 0.77 were detected in Cinnamomum verum; and 0.97 occurred in all the ingredients except in Elettaria cardamomum (Figure $3.1)$.

Under long UV, Cinnamomum verum, Elettaria cardamomum, Cinnamomum tamala, Mesua ferrea and 
CC showed 7, 3, 12, 7 and 13 bands (of different fluorescent colours) respectively. Out of 13 bands in $\mathrm{CC}, 11$ corresponded to ingredients. Bands with $\mathrm{R}_{\mathrm{f}} 0.06$ was found in all the ingredients except in Elettaria cardamomum; 0.11 was from Cinnamomum verum and 0.28 was from Cinnamomum tamala; 0.36, 0.38. 0.49 and 0.53 were from Cinnamomum verum; 0.46 and 0.79 occurred commonly in all the ingredients; 0.60 was observed in all the ingredients except in Elettaria cardamomum; 0.98 was detected in Cinnamomum tamala and Mesua ferrea (Figure 3.2).

After derivatisation with VS, Cinnamomum verum, Elettaria cardamomum, Cinnamomum verum, Mesua ferrea and CC showed 5, 3, 12, 15 and 16 bands (of different colours) respectively. Except for band with $\mathrm{R}_{\mathrm{f}} 0.92$, all other 15 spots corresponded to ingredients. Spots with $\mathrm{R}_{\mathrm{f}} 0.04,0.11,0.17,0.26,0.49,0.60$ and 0.83 were from in Mesua ferrea; 0.07, 0.24, 0.53, 0.57, 0.65 and 0.78 were from in Cinnamomum verum and Mesua ferrea; 0.37 (Purple) was observed common in all the ingredients; 0.41 was occurred in Cinnamomum verum. Most of the spots occurred from Naga kesara (Mesua ferrea) (Figure 3.3).

HPTLC fingerprinting was attempted for the detection of possible substitution of $M$. ferrea in CC with Mammea suriga with a qualitative fingerprint.

TLC photo documentation of Caturjata Curna formulation with Mesua ferrea and Mammea suriga

Under short UV, bands with $\mathrm{R}_{\mathrm{f}} 0.75$ (dark green), 0.82 (green) and 0.88 (green) in $\mathrm{CC}$ corresponded with $M$. suriga, which is not found in CC with $M$. ferrea. In densitogram at $254 \mathrm{~nm} M$. ferrea shows diagnostic peak at $\mathrm{R}_{\mathrm{f}} 0.40$, while $M$. suriga shows twin peaks at $\mathrm{R}_{\mathrm{f}} 0.36$ and 0.40 . A unique peak was observed at $\mathrm{R}_{\mathrm{f}} 0.85$ (46.58\% area) in $M$. suriga which can be used as a diagnostic peak to tap authentic ingredient. The chromatogram can be an effective tool to identify the $\mathrm{CC}$ prepared using authentic and substitute drugs (Figure $3 \& 4$ ).

Figure 3. TLC photo documentation of chloroform extract of ingredients with Caturjata curna $(4 \mu \mathrm{l})$

3.1 Under short UV

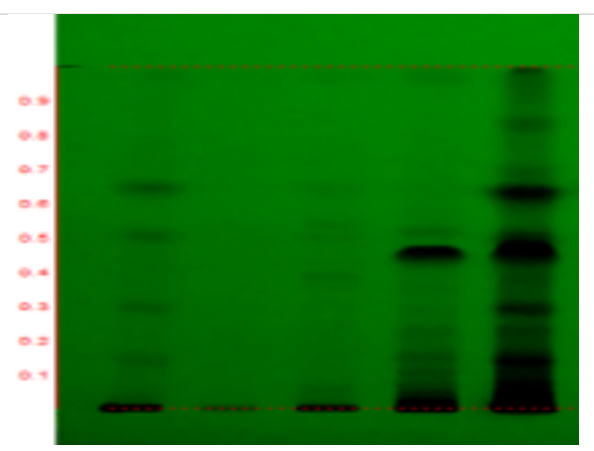

Solvent system: Toluene: ethyl acetate: formic acid (4.5: 0.5: 0.1)

1 - Tvak (Cinnamomum verum); 2 - Ela (Elettaria cardamomum); 3 - Tvakpatra (Cinnamomum tamala); 4 Nagakesara (Mesua ferrea); 5 - Caturjata curna.

\section{Figure 4. TLC photo documentation of Caturjata curna formulation with Mesua ferrea and Mammea suriga}

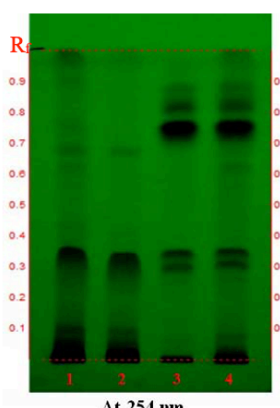

At $254 \mathrm{~nm}$

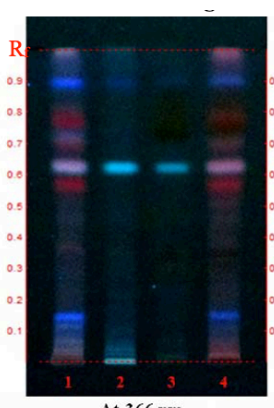

At $366 \mathrm{~mm}$

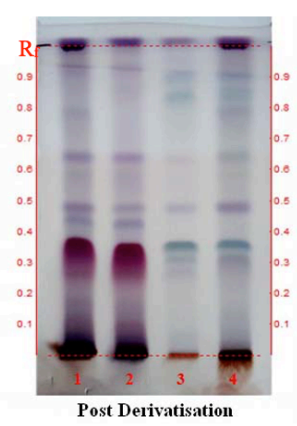

Post Derivatisation

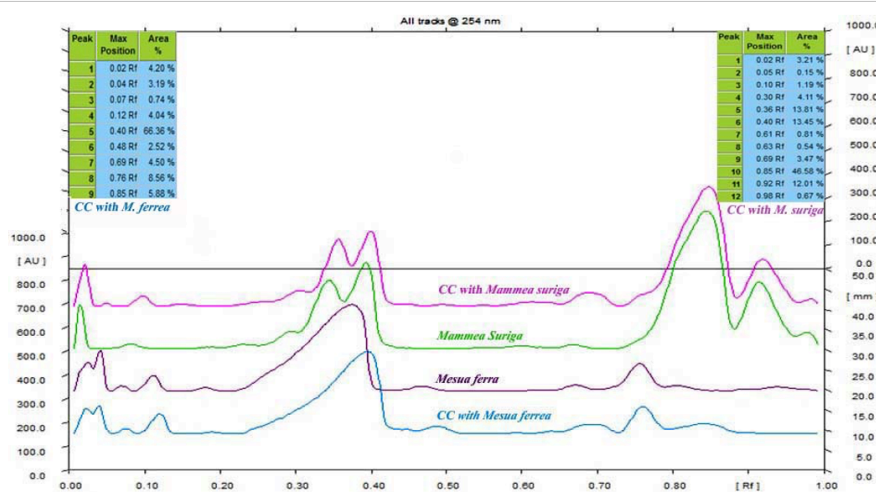

Track 1 - Caturjata curna with Mesua ferrea - $16 \mu \mathrm{l} ; 2$ - Mesua ferrea - $4 \mu \mathrm{l} ; 3$-Mammea suriga - $4 \mu \mathrm{l} ; 4$ - Caturjata curna with Mammea suriga $-16 \mu 1$

Solvent system: Toluene: ethyl acetate (5: 1)

Identification of marker compound by GC-MS and NMR Studies

GC-MS of chloroform extract yielded 7 peaks from $\mathrm{CC}$ with $\mathrm{RT}$ and area \% details as mentioned in
Figure 3-4. Two compounds 1-eicosene and transcinnamaldehyde have been identified NMR studies and confirmed by GC-MS analysis (Figure $5 \& 6$ ). In ${ }^{1} \mathrm{H}$ nmr spectrum (Figure $7 \mathrm{~b}$ ) of the $\mathrm{CC}$ extract showed 
Sunil Narayana K N et.al., Quality Standards for Caturjata curna-A Polyherbal Powder Formulation of Ayurveda

several signals. A doublet of doublet $(J=16$ and $7 \mathrm{~Hz})$ and doublet $(J=7 \mathrm{~Hz})$ and 9.7 and 6.7 ppm respectively was due to the presence of trans-cinnamaldehyde. The ${ }^{13} \mathrm{C} \mathrm{nmr}$ signals of trans-cinnamaldehyde were found at 131, 134152 and 191 ppm (Figure 7a). The presence of 1-eicosene was identified by the ${ }^{13} \mathrm{C} \mathrm{nmr}$ signals at 139 and $114 \mathrm{ppm}$ which is due olefinic carbons. The ${ }^{1} \mathrm{H}$ nmr signal due to olefenic protons of 1-eicosene appeared as multiplets around 4.9 and $5.8 \mathrm{ppm}$. The signals due to aliphatic protons and carbons appeared in the region of 0.8-2.8 ppm and 11-35 ppm respectively. Further, cinnamaldihyde is the major compound of one of the ingredient Cinnamomum verum bark (16) and it is also present in $C$. tamala leaves (17). It is suggested that the identified marker is abundant in the formulation and hence can be used as analytical marker for quality control of $\mathrm{CC}$.

Figure 5. GLC of Caturjata curna and details of compounds eluted

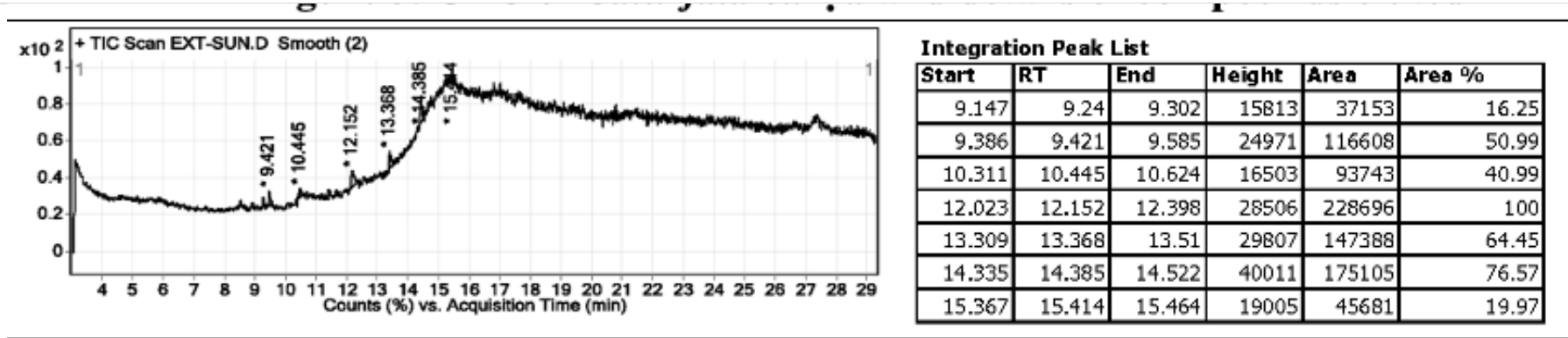

Figure 6. Mass spectra of compounds eluted by GLC of Caturjata cūrṇa

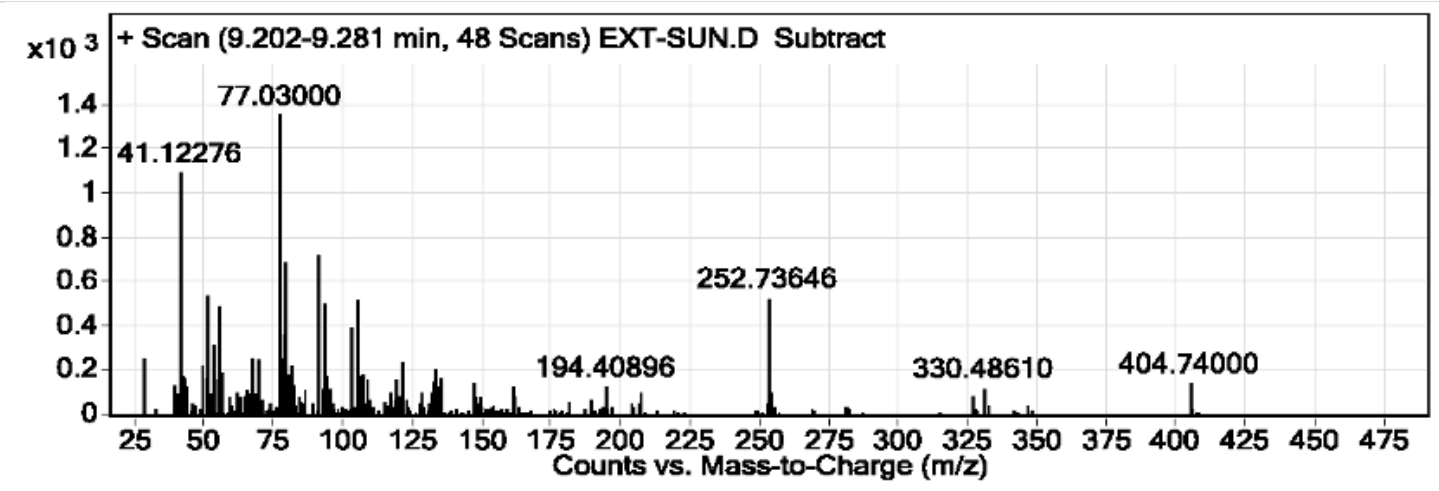

Peak List
\begin{tabular}{|l|l|}
\hline $\boldsymbol{m} / \boldsymbol{z}$ & Abund \\
\hline 41.12276 & 1099.88 \\
\hline 50.93151 & 547.83 \\
\hline 55.07 & 493.6 \\
\hline 77.03 & 1359.85 \\
\hline 78.92501 & 689.52 \\
\hline 90.9 & 724.8 \\
\hline 92.76 & 502.85 \\
\hline 102.85 & 396.02 \\
\hline 104.77044 & 518.33 \\
\hline 252.73646 & 532.68 \\
\hline Peak List & \\
\hline $\boldsymbol{m} / \boldsymbol{z}$ & Abund \\
\hline 28.11525 & 725.19 \\
\hline 43.1118 & 415.07 \\
\hline 56.96732 & 882.89 \\
\hline 76.94 & 346.47 \\
\hline 77.86 & 488.07 \\
\hline 90.84 & 739.1 \\
\hline 130.69147 & 363.27 \\
\hline 190.8495 & 3185.11 \\
\hline 191.01 & 687.94 \\
\hline 191.87157 & 349.99 \\
\hline &
\end{tabular}
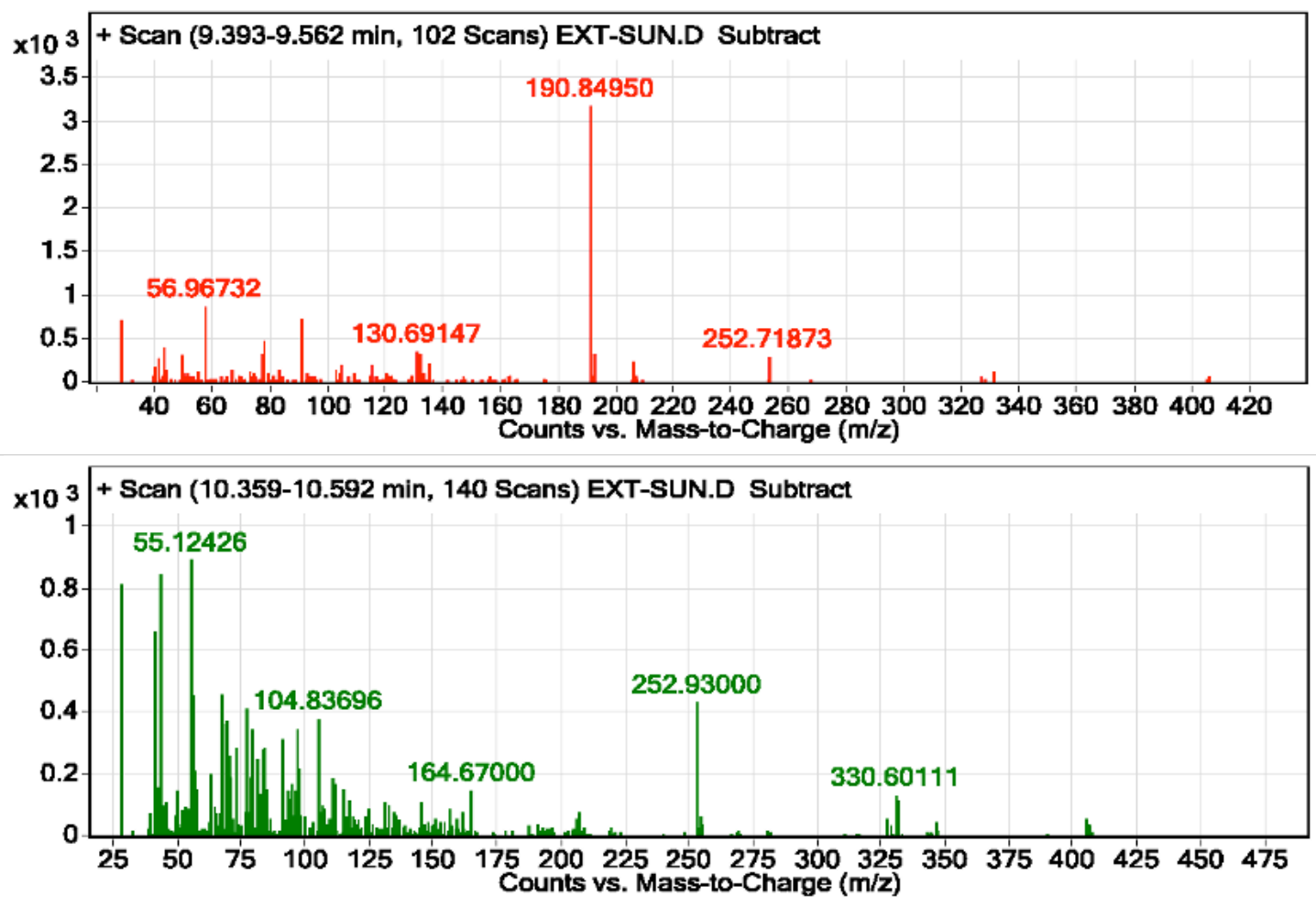

Peak List
\begin{tabular}{|l|l|}
\hline $\boldsymbol{m} / \boldsymbol{z}$ & Abund \\
\hline 28 & 811.54 \\
\hline 41.14369 & 664.46 \\
\hline 43.11118 & 846.35 \\
\hline 55.12426 & 894.96 \\
\hline 55.96 & 456.49 \\
\hline 66.85 & 462.26 \\
\hline 69.05 & 376.68 \\
\hline 76.95 & 412.99 \\
\hline 104.83696 & 382.42 \\
\hline 252.93 & 434.78 \\
\hline
\end{tabular}




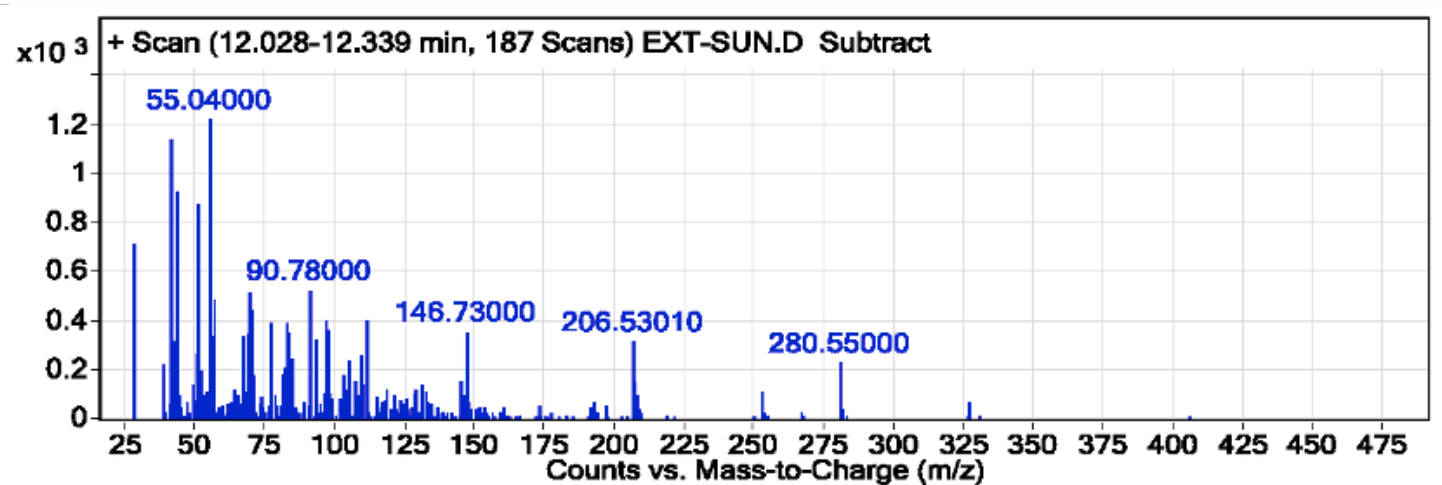

Peak List
\begin{tabular}{|l|l|}
\hline$m / \boldsymbol{z}$ & Abund \\
\hline 28.2 & 721.42 \\
\hline 41.21436 & 1142.35 \\
\hline 43.14554 & 934.45 \\
\hline 51.06204 & 882.65 \\
\hline 55.04 & 1227.97 \\
\hline 56.88 & 484.79 \\
\hline 57.00673 & 493.23 \\
\hline 69.03002 & 522.77 \\
\hline 70.05771 & 450.74 \\
\hline 90.78 & 530 \\
\hline
\end{tabular}

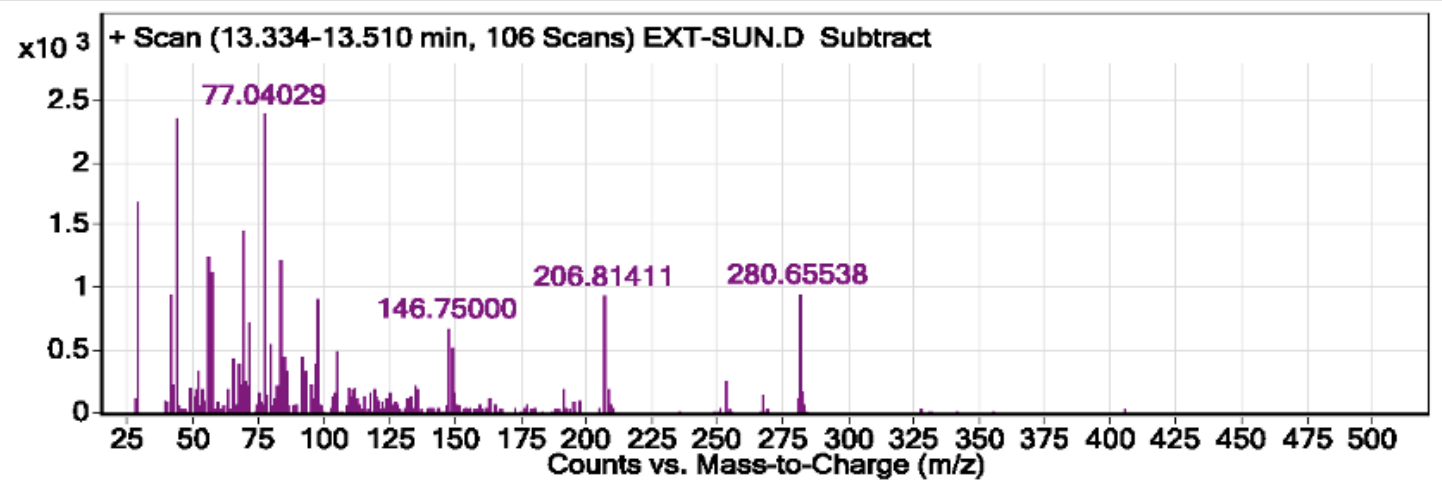

Peak List
\begin{tabular}{|l|l|}
\hline $\boldsymbol{m} / \boldsymbol{z}$ & Abund \\
\hline 28.2 & 1690.97 \\
\hline 41.14185 & 957.26 \\
\hline 43.23773 & 2360.62 \\
\hline 55.04656 & 1264.1 \\
\hline 57.04 & 1139.02 \\
\hline 68.97 & 1469.98 \\
\hline 77.04029 & 2398.34 \\
\hline 83.03432 & 1240.54 \\
\hline 206.81411 & 945.4 \\
\hline 280.65538 & 963.59 \\
\hline
\end{tabular}

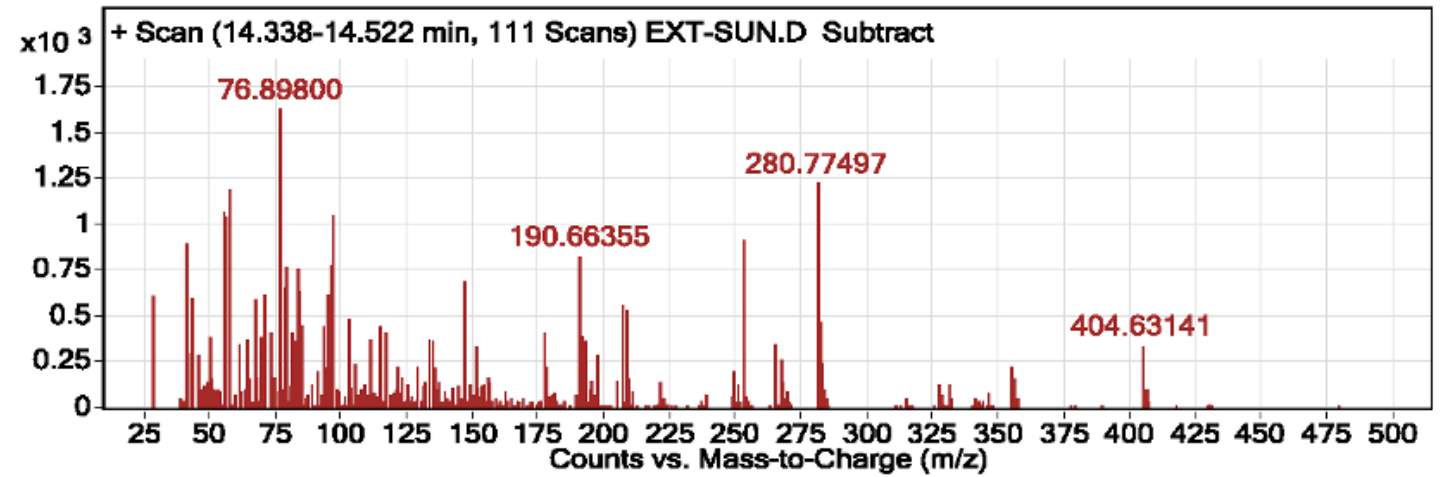

Peak List
\begin{tabular}{|l|l|}
\hline $\boldsymbol{m} / \boldsymbol{z}$ & Abund \\
\hline 41.14578 & 903.46 \\
\hline 55.13157 & 1080.66 \\
\hline 56.05 & 1051.39 \\
\hline 57.04374 & 1192.19 \\
\hline 76.898 & 1637.21 \\
\hline 96.13 & 784.29 \\
\hline 96.94804 & 1056.62 \\
\hline 190.66355 & 835.11 \\
\hline 252.6 & 919.78 \\
\hline 280.77497 & 1233.29 \\
\hline Peak List & \\
\hline $\boldsymbol{m} / \boldsymbol{z}$ & Abund \\
\hline 41.22153 & 2338.29 \\
\hline 57.11625 & 967.31 \\
\hline 69.06147 & 991.54 \\
\hline 70.89 & 985.82 \\
\hline 74.95 & 1171.53 \\
\hline 96.07065 & 1661.69 \\
\hline 96.95 & 1473.38 \\
\hline 132.7693 & 2811.02 \\
\hline 252.85926 & 1545.76 \\
\hline 280.92433 & 3359.34 \\
\hline
\end{tabular}

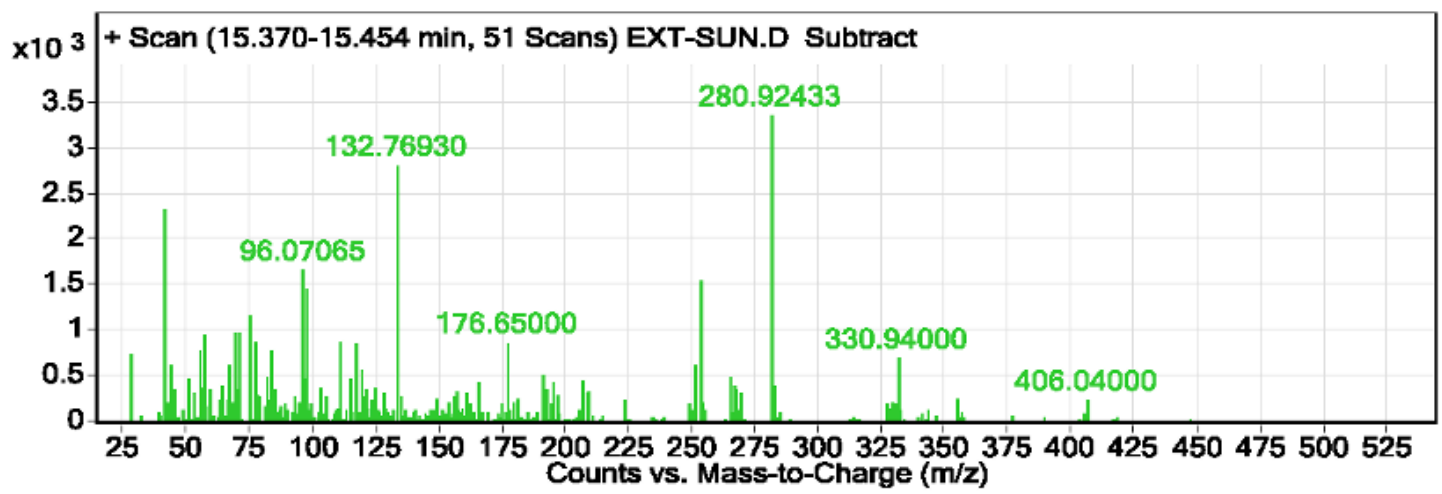

\section{Discussion}

Adulteration/substitution is the major drawback in herbal products. In CC, Mammea suriga has been used as a substitute/adulterant. Adulteration is the practice of substituting the original crude drug partially or fully with other substances which is either free from or inferior in therapeutic and chemical properties or addition of low grade or spoiled or spurious drugs or entirely different drug similar to that of original drug substituted with an intention of enhancement of profits (18).
$M$. ferrea is morphologically and chemically
etely different from $M$. suriga, the former being completely different from $M$. suriga, the former being
stamens it is coppery or golden brown colour; fragrant and possess astringent taste (19). Major chemical constituents of Mesua ferrea are mesuaferrol (20) and mesuanic acid $(21,22)$. M. suriga is a flower bud reddish-brown in colour, odour and taste faint and characteristic. Majorly it contains proanthocyanidins (23) and vitexin (24). The pharmacological actions of the two sources of Mesua ferrea would be different as they are chemically different.

There are very few attempts to identify marker compounds from extracts using MS or NMR. In some 
Sunil Narayana K N et.al., Quality Standards for Caturjata curna-A Polyherbal Powder Formulation of Ayurveda

studies, NMR has been used just as a fingerprinting tool. This study could identify a major compound of the formulation by employing GC-MS and NMR spectroscopy. Every AYUSH formulation must be studied to obtain these kinds of fingerprints along with conventional chromatography to raise the standards of the monograph on quality standards by identifying a compound present in it. Very few $(25,26)$ such monographic documents on standards of polyherbal formulations are published with high standards. There is a need for proposing reproducible data on standards of such formulations for worldwide acceptance of Ayurvedic polyherbal medicines.

Despite the establishment of the Drugs and Cosmetic Act to control the manufacture and quality control the regulation of Ayurvedic herbal preparation manufacturing is somewhat less stringent in India where most of the Ayurvedic polyherbal formulations are manufactured and exported. Since toxicity studies and clinical trials on herbal formulations are not mandatory for patent application and manufacturing license application (27), standardisation is not up to the mark. Standardisation of polyherbal formulations has been a challenging job for the regulators like Pharmacopoeial Commission of Indian Medicine and Homeopathy New Delhi as there are several formulations popular in Ayurvedic practice while very few have been standardised and Pharmacopoeial monographs published so far.

Figure 7 a. ${ }^{13} \mathrm{C}\{1 \mathbf{H}\}$ NMR Spectra of Caturjata cūrṇa extract

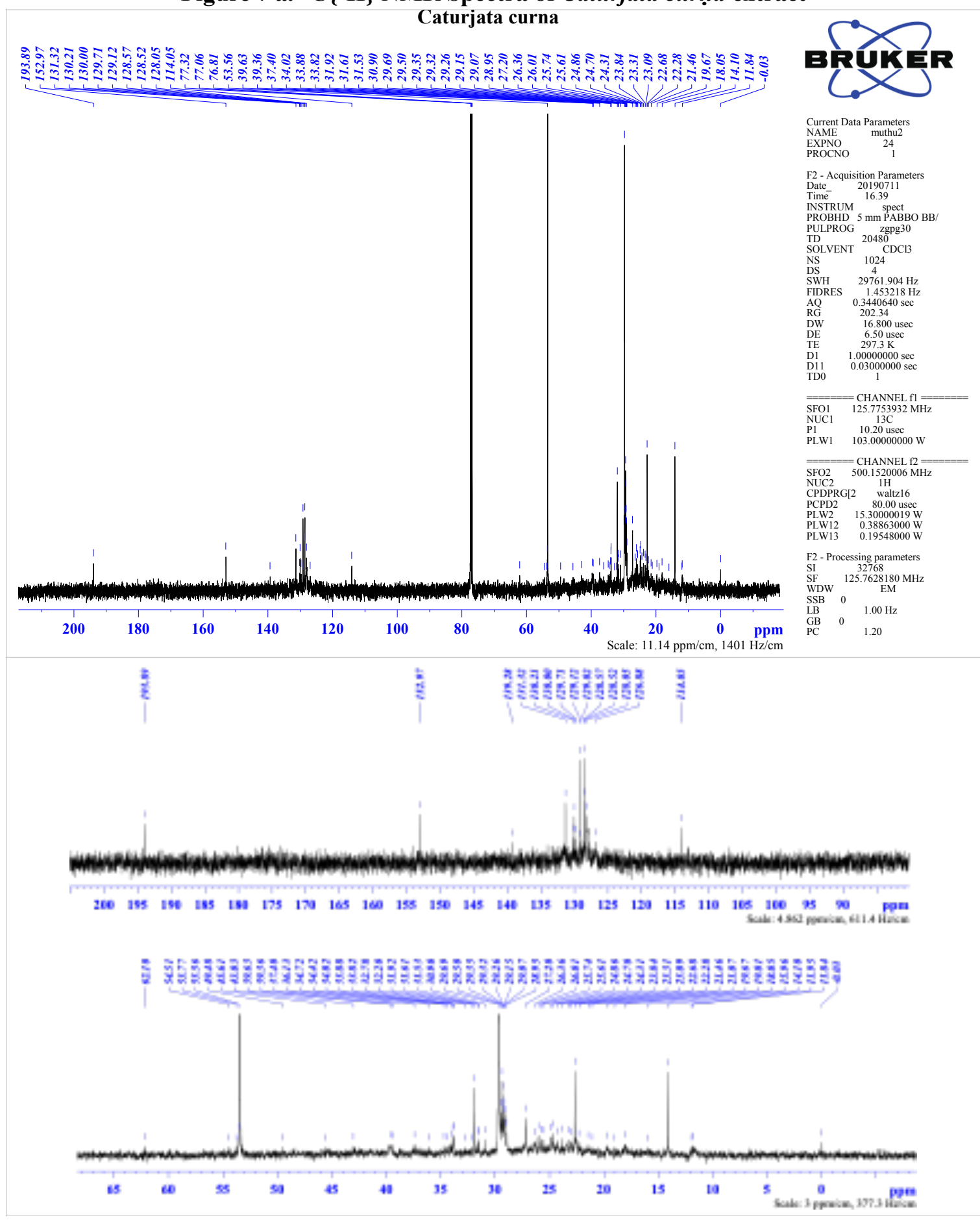


Figure 7 b.1 ${ }^{1}$ NMR Spectra of Caturjata curna extract Caturjata curna

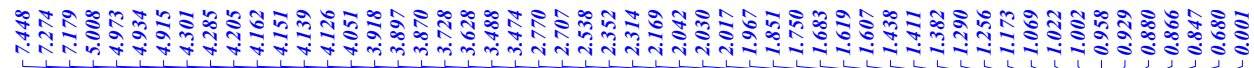

BRUKER

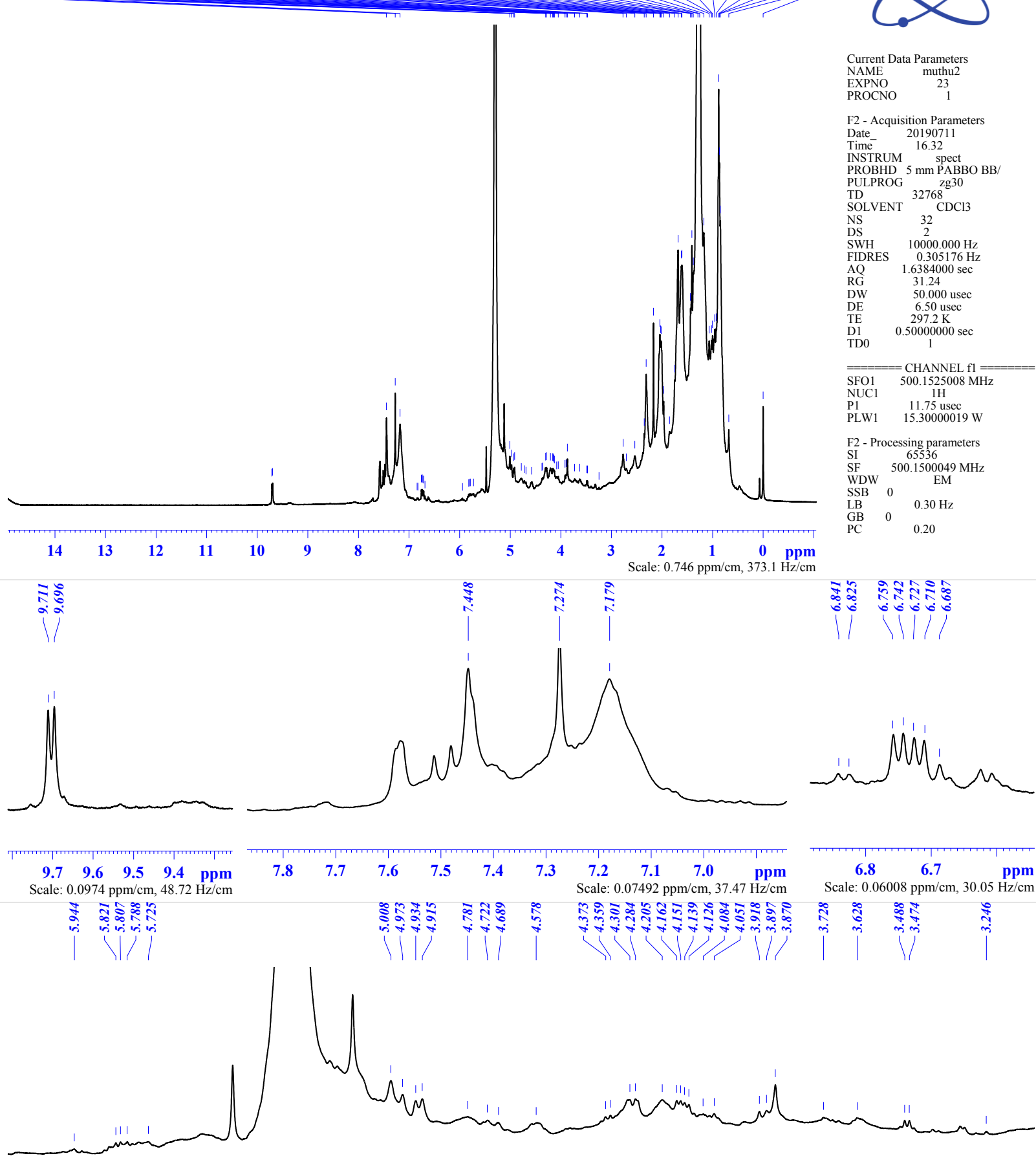

$\begin{array}{llllllllllllllllllllllllllllll}6.1 & 6.0 & 5.9 & 5.8 & 5.7 & 5.6 & 5.5 & 5.4 & 5.3 & 5.2 & 5.1 & 5.0 & 4.9 & 4.8 & 4.7 & 4.6 & 4.5 & 4.4 & 4.3 & 4.2 & 4.1 & 4.0 & 3.9 & 3.8 & 3.7 & 3.6 & 3.5 & 3.4 & 3.3 & \text { ppm }\end{array}$

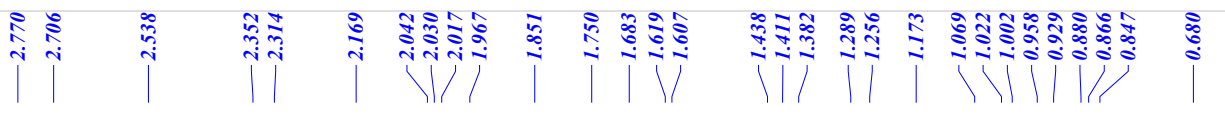

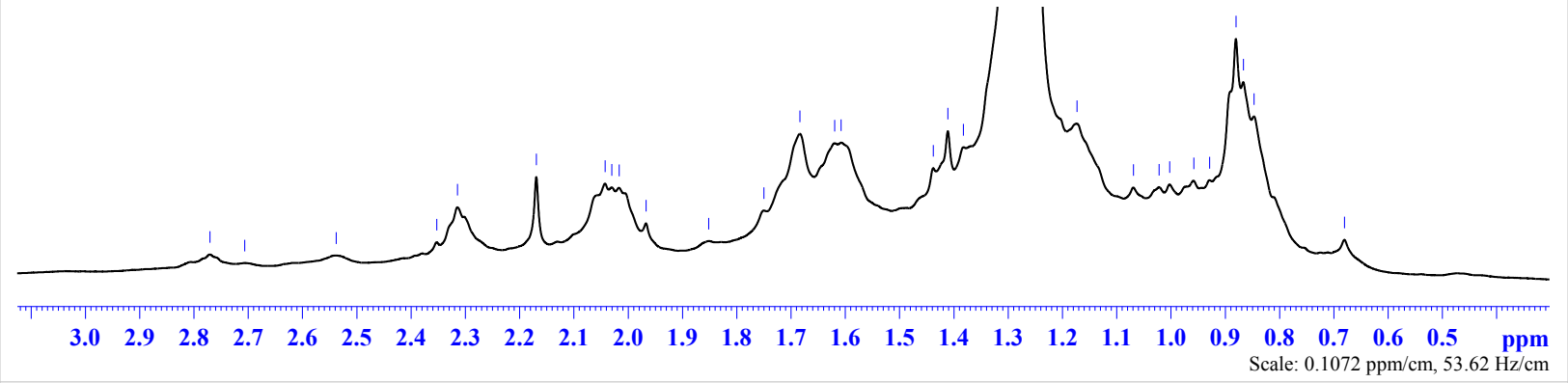


Sunil Narayana K N et.al., Quality Standards for Caturjata curna-A Polyherbal Powder Formulation of Ayurveda

\section{Conclusion}

From the result obtained the monographic data on quality standards for CC can be laid as follows:

\section{Definition}

Caturjata curna is a fine powder preparation made with the ingredients in the formulation composition given below.

\section{Formulation composition}

\begin{tabular}{|l|l|l|}
\hline Cinnamomum zeylanicum & Stem Bark & 1 part \\
\hline Elettaria cardamomum & Seed & 1 part \\
\hline Cinnamomum tamala & Leaf & 1 part \\
\hline Mesua ferrea & Stamen & 1 part \\
\hline
\end{tabular}

\section{Methods of preparation}

Take all ingredients of pharmacopoeial quality. Wash and dry all the ingredients. Powder all the ingredients and should completely pass through sieve number 44 and not less than 50 percent through sieve number 85 . Weigh each ingredient separately and mix together. Pass the cūrna through sieve number 44 to obtain a homogenous blend and pack in an air-tight container.

\section{Description}

Caturjata curna is brown coloured fine powder with characteristic odour and aromatic taste.

\section{Identification \\ Microscopy}

Show sparenchyma with tannin and volatile oil, horse shoe shaped stone cells, narrow lumened thickwalled tapering ended fibres (Cinnamomum verum); cells of testa with reddish brown contents, irregularly walled perisperm cells with volatile oil droplets (Ela); unicellular conical covering trichomes with attached basal cells, epidermis in surface view with paracytic stomata (Cinnamomum verum); trichome with pointed and blunt tip, polygonal beaded epidermal cells of anther, endothecium layers of anthers (Mesua ferrea).

\section{Thin Layer Chromatography}

Under short UV 13 bands occurred in CC, of them 11 corresponded in $\mathrm{R}_{\mathrm{f}}$ to bands from ingredients. Under long UV CC showed 13 bands out of which 11 corresponded to ingredients. After derivatisation with VS CC showed 16 bands. Except for band with $\mathrm{R}_{\mathrm{f}} 0.92$, all other 15 spots corresponded to ingredients. HPTLC fingerprinting was attempted for the detection of possible substitution of M. ferrea in CC with Mammea suriga with a qualitative fingerprint.

\section{Physico-chemical standards}

- Loss on drying at $105^{\circ}$ : Not more than 10.39 per cent.

- Total ash: Not more than 4.1 per cent.

- Acid-insoluble ash: Not more than 0.90 per cent.

- Ethanol soluble extractive: Not less than 10 per cent.

- Water - soluble extractive: Not less than 8.77 per cent.

- pH of 10\% aqueous solution: Not more than 4.58 .

\section{Spectroscopic studies}

Presence of cinnamaldehyde and 1-eicosene were confirmed by GC-MS and NMR studies.

\section{Other Requirements}

Microbial limits, aflatoxin, heavy metals, pesticide residue, and radioactive contaminants: Nil/Within limits of WHO.

\section{Adulterants and substitutes}

Mammea suriga is used as Mesua ferrea. Incorporation of substitute drug $M$. suriga shows presence of epidermis of petal with striated cuticle and pollen grains with warty exine. $M$. suriga renders high total ash $(+1.49)$, low ethanol soluble extractive $(-2.85)$ and high water soluble extractive $(+0.98)$. In densitogram at $254 \mathrm{~nm} M$. suriga shows twin peaks at $\mathrm{R}_{\mathrm{f}} 0.36$ and 0.40 and a unique peak at $\mathrm{R}_{\mathrm{f}} 0.85$ (46.58\% area).

\section{Storage}

Store in a cool, dry place in tightly closed containers, protect from light and moisture.

\section{Therapeutic uses}

Tastelessness; diseases due to visitation of Kapha; poisonous bites; discoloration of skin.

Dose: 2 to $4 \mathrm{~g}$.

Anupana: Honey, ghee, water.

With the data obtained in the current investigation a monograph on quality standards for Caturjata curna of Ayurvedic Formulary of India has been proposed. This type of research is essential for deriving consistent standards with rapid authentication fingerprints as a contributing to herbal Pharmacopoeias.

\section{Declaration of Interest}

Authors declare that there are no conflicts of interest.

\section{Funding Sources}

This work was supported by UGC Major Research Project (F. No. 41-733/2012 (SR) dated 23 ${ }^{\text {rd }}$ July, 2012.

\section{References}

1. Guidelines on Quality of Herbal Medicinal Products. European Agency for the Evaluation of Medicinal products (EMEA), London, 1998.

2. Mathew L, Babu S. Phytotherapy in India: Transition of tradition to technology. Curr Bot 2011;2:17-22.

3. Kunle O.F.E, Henry O, Ahmadu P.O. Standardisation of herbal medicines - A review. International Journal of Biodiversity and Conservation 2012;4:103.https://doi.org/10.5897/ IJBC11.163

4. Shailajan S, Menon S.N. Polymarker based standardization of an Ayurvedic formulation, 
Lavangadivati using high performance thin layer chromatography. J Pharmacy Res 2011;4:467-470.

5. Adesokan A.A, Yakubu M.T, Owoyele B.V, Akanji M.A, Soladoye A.O, Lawal O.K. Effect of administration of aqueous and ethanolic extracts of Enantia chlorantha stem bark on brewer's yeastinduced pyresis in rats. Afr $\mathrm{J}$ Biochem Res 2008;2:165-169.

6. Chakravarthy B.K. Standardization of herbal products. Indian J Nat Prod1993;9:23-26.

7. Shailaja Srivastava, editor (4th Ed). Sharangadhar Samhita of Acharya Sharangadhar. Varanasi: Chaukhambha Orientalia, 2005.

8. Parasuraman S, Kumar E.P, Kumar A, Emerson S.F. Anti-hyperlipidemic effect of triglize, a polyherbal formulation. Int J Pharm PharmSci 2010;2:118122.

9. Dey Y.N, Kumari S, Ota S, Srikanth N. Phytopharmacological review of Andrographis paniculata (Burm.f) Wall. exNees. Int J Nutr Pharmacol Neurol Dis 2013;3:3-10.https://doi.org/ 10.4103/2231-0738.106973

10. Ayurvedic Formulary of India. 1st ed. Part I. New Delhi: Department of Indian Systems of Medicine and Homoeopathy, Ministry of Health and Family Welfare, Government of India, 2003. 108 p.

11. Pushpendra, Sunil Kumar K.N, PriyadarshiniHolla B.S, Ravishankar B, Yashovarma B. Simple modus operandi to bring down microbial load of herbal drugs to Pharmacopoeial limit - A study on ingredients of Hutabhugadi curna. Journal of Scientific and Innovative Research 2014;2:1040-1043.

12. The Ayurvedic Pharmacopoeia of India. Part II (Formulations), 1st ed. Vol I. New Delhi: Ministry of Health and Family Welfare, Dept. of AYUSH, Govt. of India, 2007; 79-89 p.

13. The Ayurvedic Pharmacopoeia of India. Part I, Vol VI. New Delhi: Ministry of Health and Family Welfare, Dept. of AYUSH, Govt. of India, 2008. 233-291 p.

14. Sunil Kumar K.N, Saraswathy A, Amerjothy S. HPTLC Fingerprinting of extracts of Mango Mistletoe- Helicanthu selastica (desr.) Danser with multiple markers. J SciInno Res 2013;2(5):864-871.

15. Koppala Narayana S.K, Priyadarshini, Puneeth, Prabhu S.N, Ballal M. Chemical fingerprints for Panchavalkala Kvātha Curna. J Ayu Med Sci 2018;3(2):356-368. https://doi.org/10.5530/ jams.2018.3.16

16. Ross M.S.F. Analysis of cinnamon oil by high pressure liquid chromatography. J Chromatogr 1976;118:273-275. https://doi.org/10.1016/ S0021-9673(00)81222-4
17. Nath S.C, Hazarika A.K, Singh R.S. Essential oil of leaves of Cinnamomum tamala Nees. \& Eberm. from North East India. J Spices Aromat Crops 1994;3:33-35.

18. Kokate C.K, Purohit A.P, Gokhale S.B. Pharmacognosy. 39 th ed. Pune: Nirali Prakashan, 2007; 97-98 p.

19. Shome U, Mehrotra S, Sharma H.P. Pharmacognostic study of flower of Mesua ferrea Linn. Proc Indian AcadSci (Plant Sci) 1982;91:211-226.

20. Dennis T.J, Akshaya Kumar K, Srimannarayana G. A new cyclohexadione from Mesua ferrea. Phytochemistry 1998;27:2325-2327.https:// doi.org/10.1016/0031-9422(88)80153-5

21. Raju M.S, Srimannarayana G, Rao N.V.S. Structure of mesuaferrone-B a new biflavanone from the stamens of Mesua ferrea Linn. Tetrahedron Lett 1976;49:4509-12.https:// doi.org/10.1016/0040-4039(76)80156-6

22. Raju M.S, Srimannarayana G, Rao N.V.S. Structure of mesuanic acid. Indian $\mathrm{J}$ Chem 1974;12: 884-886.

23. Rao L.J.M, Yada H, Ono H, Ohnishi-Kameyama M, Yoshida M. Occurrence of antioxidant and radical scavenging pro-anthocyanidins from the Indian minor spice nagkesar (Mammea longifolia Planch and Trianasyn). Bioorg Med Chem 2004;12:32-36.https://doi.org/10.1016/ j.bmc.2003.10.052

24. Khan M.S.Y, Kumar I, Khan N.U, Ilyas M. Chemical investigation of Indian medicinal plants used for leprosy. i. Constituents of the flowers of Ochrocarpus longifolius Benth. And Hppk. f. (Guttiferae). CurrSci 1978;47:414-415.

25. Pushpendra, Sunil Kumar K, Priyadarshini, Holla B.S, Ravishankar B, Yashovarma B. Quality standards for Hutabhugadicurna (Ayurvedic Formulary of India). Journal of Traditional and Complementary Medicine 2016;6:78-88. https://doi.org/10.1016/ j.jtcme.2014.11.019

26. Sunil Kumar K.N, Priyadarshini, Ravishankar B, Yashovarma B. Quality standards for Bhūnimbādi Kvātha Curna. J Ayu Med Sci 2016;1:19-33. https://doi.org/10.5530/ jams.2016.1.4

27. Munshi R, Bhalerao S, Kalekar S. Proceedings of Seminar on Regulatory Aspects of Herbal Products. J Ayurveda Integr Med 2012;3:168172. 